A.L. Petranovska ${ }^{1}$, M.V. Abramov ${ }^{1}$, N.M. Opanashchuk ${ }^{1}$, S.P. Turanska ${ }^{1}$, P.P. Gorbyk ${ }^{1}$, N.V. Kusyak ${ }^{2}$, A.P. Kusyak ${ }^{2}$, N.Yu. Lukyanova ${ }^{3}$, V.F. Chekhun ${ }^{3}$

\title{
MAGNETICALLY SENSITIVE NANOCOMPOSITES AND MAGNETIC LIQUIDS BASED ON MAGNETITE, GEMCITABINE, AND ANTIBODY HER2
}

\author{
${ }^{1}$ Chuiko Institute of Surface Chemistry of National Academy of Sciences of Ukraine \\ 17 General Naumov Str., Kyiv, 03164,Ukraine, E-mail: phorbyk@ukr.net \\ ${ }^{2}$ Ivan Franko Zhytomyr State University \\ 40 V. Berdychivska Str., Zhytomyr, 10008, Ukraine \\ ${ }^{3}$ R.E. Kavetsky Institute of Experimental Pathology, Oncology and Radiobiology of National Academy of Sciences of Ukraine \\ 45 Vasylkivska Str., Kyiv, 03022, Ukraine
}

The processes of adsorption of gemcitabine $(G C)$ on the surface of nanosized singledomain magnetite $\left(\mathrm{Fe}_{3} \mathrm{O}_{4}\right)$ have been investigated. Under the experiment conditions, the value of adsorption capacity $A$ was $\sim 37.2 \mathrm{mg} / \mathrm{g}$, the extraction extent $U=33.13 \%$, the separation factor $E=82.58 \mathrm{~mL} / \mathrm{g}$. It has been determined that adsorption corresponds to the Freundlich model. The magnetic properties of nanocomposites (NC) $\mathrm{Fe}_{3} \mathrm{O}_{4} @ G C$ have been investigated. The average value of the thickness of the adsorbed layer of $\mathrm{GC}$ in the composition of $\mathrm{Fe}_{3} \mathrm{O}_{4} @ G C \mathrm{NC}$ is $2.4 \pm 0.1 \mathrm{~nm}$, as evaluated by the method of magnetic granulometry. Magnetic liquids (ML) have been synthesized based on magnetite and physiological solution (PS) stabilized with sodium oleate (Ol.Na) and polyethylene glycol (PEG), which contain GC and antibody (AB) HER2 (Fe $\left.\mathrm{O}_{4} @ G C / O l . N a / P E G+P S\right)$. The properties of ML were investigated as well as cytotoxic/cytostatic activity with respect to HepG2 hepatocellular carcinoma of human liver.

Parameters of $\mathrm{ML}$ based on magnetite were found: $\mathrm{Fe}_{3} \mathrm{O}_{4}$ concentration - $14 \mathrm{mg} / \mathrm{mL}, \mathrm{Fe}_{3} \mathrm{O}_{4}$ particle size 4-22 $\mathrm{nm}$, average size of $\mathrm{Fe}_{3} \mathrm{O}_{4}$ particles $-10.8 \mathrm{~nm}$; the average size of $\mathrm{Fe}_{3} \mathrm{O}_{4}$ particles stabilized with sodium oleate - $16.8 \mathrm{~nm}$, saturation magnetization $M_{\infty}=14.1 \pm 2.5 \% \mathrm{Gs}$, hypsometric height $-25 \pm 10 \% \mathrm{~cm}$, viscosity $\eta=1.14 \pm 3 \% \mathrm{mPa} \cdot \mathrm{s}$, density $\rho_{M L}=1.14 \pm 1.0 \% \mathrm{~g} / \mathrm{cm}^{3}$, the concentration of $\mathrm{GC}$ was $1.25 \mathrm{mg} / \mathrm{mL}$, that of HER $\mathrm{AB}$ was $3.75 \mu \mathrm{g} / \mathrm{mL}$. We have obtained the calculated and graphic data concerning the dependence of the surface area and the specific magnetization of saturation of $\mathrm{Fe}_{3} \mathrm{O}_{4} @ G C / O l . N a / P E G$ on the thickness of GC layer, which can be useful for predicting of the nanoscale architecture of magnetically sensitive $N C$ and $M L$ in the manufacture of relative drugs. The synergistic nature of the influence of $\mathrm{GC} / \mathrm{Fe}_{3} \mathrm{O}_{4} / \mathrm{HER} 2$ complex on HepG2 cells was revealed. It has been determined that IC50 for ML is $0.155 \mathrm{mg} / \mathrm{mL}$, in the range of concentration of $0.025-0.1 \mathrm{mg} / \mathrm{mL}, \mathrm{ML}$ is biocompatible with HepG2 cells. It has been shown that HER2 AB used alone in the investigated concentrations does not affect HepG2 cell viability/proliferation. In vitro, GC inhibits the proliferation of liver carcinoma cells, the IC50 value has been $0.002 \mathrm{mg} / \mathrm{mL}$. The use of ML in complex with GC can increase the cytotoxic activity of the composite by $8-10 \%$. The $M L+G C+H E R 2 A B$ complexes caused the synergistic effect and an increase in the cytotoxic activity, compared with GC used alone, up to $18-20 \%$, while GC contents reduced to $0.008 \mathrm{mg} / \mathrm{mL}$.

The results of the studies indicate that the use of ML based on magnetite, gemcitabine, and antibody increases the effectiveness of the antitumor medicines with a significant reduction in their dose and, respectively, the toxicoallergic reactions of the body, and nanosized magnetite can be promising for the manufacture of magnetically sensitive adsorption materials for medical purposes, e.g. for detoxification of an organism after GC therapy.

Keywords: magnetite, magnetic liquids, gemcitabine, antibody HER2, hepatocellular carcinoma of human liver

\section{INTRODUCTION}

At the beginning of the 21 st century, the works in the field of creation of medicobiological and biotechnological nanomachines and "nanoclinics" have got a priority [1-4]. In these works $[5,6]$, the ideas have been developed for creation of multilevel magnetically sensitive nanocomposites (NC) with a hierarchical nanostructure, which [7,8] (C) A.L Petranovska, M.V. Abramov, N.M. Opanashchuk, S.P. Turanska, P.P. Gorbyk, N.V. Kusyak, A.P. Kusyak, N.Yu. Lukyanova, V.F. Chekhun, 2019 have a complex of functions characteristic for biomedical nanorobot: recognition of microbiological objects in biological environments; targeted delivery of medicines to specific cells and organs, and deposit; complex therapy with chemo-, immune, neutron capture radiation, photodynamic, hyperthermic methods and realtime diagnostics; adsorption of cellular 
decomposition remnants, ions of heavy metals, viral particles, and their removal from the body through an external magnetic field. It should be noted that for today, the concept of magnetically sensitive $\mathrm{NC}$ with multilevel hierarchical nanoscale architecture and functions of nanorobots was experimentally substantiated and confirmed through chemical construction of core-shell type nanostructures with complex multilevel hierarchical structure, their combined research and comprehensive check of the capability to perform these functions effectively [9-19].

For in vitro and in vivo systems, the benefits of using of magnetic liquid (ML) compared to the traditional use of cisplatin (CP) have been proven [20]. It has been found that the biggest cytotoxic activity of the nanocomposite, indicated in the MCF-7/CP resistance line, is related to the most active accumulation of ferrimagnetic nanoparticles in cells due to the high level of transferrin receptors and the disturbance of the antioxidant protection system of resistant cells. It has been shown that a magnetic liquid is capable to cause more pronounced cytomorphological changes and genotoxic effects in the cells of the resistance line compared to cells of the sensitive line. Thus, it has been found that ML on the basis of magnetite and cisplatin is characterized by the capability to redox regulation of cells with phenotype of medicine resistance, which testifies the prospect of its use for pathogenetically grounded targeted therapy of malignant tumors.

It has been experimentally shown that the use of ML containing $\mathrm{NC}$ on the basis of magnetite and $\mathrm{CP}$, on the general and biochemical parameters of blood does not make more toxic effects on the body, compared with the official antitumor medicine cisplatin, in according doses.

In papers [16, 21-23] the results are presented concerning researches into $\mathrm{NC}$ made on the basis of nanosized $\mathrm{Fe}_{3} \mathrm{O}_{4}$ with modified (by hydroxyapatite, aminopropylsiloxane, polyacrylamide, etc.) surface, conjugated with $\mathrm{CP}$ and antibody (AB) $\mathrm{CD} 95$. In vitro $\mathrm{NC}$ were characterized by recognition of MCF-7 human breast cancer cells, determined activity of $\mathrm{CP}$, CD95, and synergism of their combined activity with $\mathrm{Fe}_{3} \mathrm{O}_{4}$, which resulted in vitro to the death of cells in an amount that exceeded the effect of control samples of CP and CD95 in 1.4-2.7 times as dependent on the composition of the NC.
Taking all this into consideration, it is an actual task from the scientific and practical point of view to clarify the possibility of using of the above mentioned approaches to create new effective antitumor medicines based on ML, containing magnetically sensitive $\mathrm{NC}$, other relevant chemotherapeutic medicines and antibodies [24-30]. Solving of this task can expand the functionality of NCs, improve their specificity, promote the creation of new multifunctional antitumor medicines for targeted delivery and local therapy, and provide new data concerning the interaction of oncological drugs with tumor cells.

Therefore, the purpose of this work is to synthesize new nanocomposites and magnetic liquids based on magnetite, gemcitabine and HER2 antibody, to investigate their properties and bioactivity in relation to HCC hepatic cells of HepG2 line.

\section{EXPERIMENTAL PART AND DISCUSSION}

In this work, gemcitabine - (2-deoxy-2', 2) difluorocytidine monochloride) is used as a drug of the chemotherapeutic mechanism of action. It is a cytotoxic drug, an antimetabolite from the pyrimidine antagonists group. GC belongs to the List of the main medicines of the World Health Organization and the most effective and safe medicines needed in the healthcare system. It is characterized by considerable antitumor activity for the list of solid tumors (non-small cell lung cancer, pancreatic, bladder, breast and ovarian cancer), satisfactory endurance and the capability to combine successfully with other antitumor medicines. It is used for treatment of cholangiocarcinoma and other types of biliary cancer. The general side effects include bone marrow suppression, liver and kidney problems, nausea, fever, rash, shortness of breath and hair loss [31-34]. Therefore, for today, the possibility is actively studied to use GC in composition of magnetically sensitive $\mathrm{NC}$ and ML on their basis to create multi-functional antitumor medicines for targeted delivery and local therapy [35-38].

In this work as an AB, HER2 (Neu, ErbB-2, CD340) was chosen. It is a membrane protein, a tyrosine proteinkinase of the EGFR / ErbB epidermal growth factor receptor family encoded by the human gene ERBB2. Amplification of the HER2 gene plays an important role in the pathogenesis and progression of certain aggressive types of cancer [39-41]. HER2 is an 
important biomarker and therapeutic target of the disease, associated with aggressiveness of the tumor and unfavorable prognosis. It is known that HER2 $\mathrm{AB}$ is considered to be one of the optimal for treatment of such diseases as gastrointestinal tract cancer, in particular in the presence of liver metastasis [42]. Therefore, for in vitro researches, we have chosen HER2 $\mathrm{AB}$ in combination with GC in composition of ML based on magnetite.

Hepatocellular carcinoma (HCC) is the most common primary malignant form of liver cancer, the result of malignant transformation of hepatocytes, a severe, high mortality disease. Every year in the world about 600 thousand cases of this disease are diagnosed. In order to test the antitumor activity of the synthesized ML in vitro, the cells of the HCC human liver of HepG2 line were selected in this work.

\section{METHODS OF RESEARCH}

Adsorption of $\mathrm{GC}$ on the surface of nanosized magnetite was carried out from aqueous solutions of different concentration. Gemcitabine TEVA (Pharmachemie BV, the Netherlands) was used for research.

Adsorption capacity of samples $A(\mathrm{mg} / \mathrm{g})$, extraction extent $U(\%)$, and separation factor $E$ $(\mathrm{mL} / \mathrm{g})$ were determined by techniques described in $[13,14]$.

The amount of adsorbed substance on the surface of magnetite was determined by measuring the concentration of GC in contact solutions before and after adsorption using a spectrophotometer Spectrometer Lambda 35 UV/Vis Perkin Elmer Instruments.

Specific surface area $\left(S_{s p}\right)$ of the samples was determined by nitrogen thermal desorption by means of a KELVIN 1042 device of "COSTECH Instruments" firm. The size of NP was appreciated by formula $D_{\mathrm{BET}}=6 /\left(\rho S_{\mathrm{BET}}\right)$, where $\rho$ is density of a particle of NC, $S_{\mathrm{BET}}$ is a value of specific surface area calculated by the polymolecular adsorption theory of Brunauer, Emmett and Teller (BET).

The hysteresis loops of the magnetic moment of the samples were measured using a laboratory vibration magnetometer of Foner type at the room temperature. The description of the installation and the method of measurement are set out in [43]. To prevent interactions, the demagnetized nanoparticles were distributed in the paraffin matrix with a volume concentration of $\sim 0.05$. For comparison, materials were used with known values of specific saturation magnetization $\left(\sigma_{s}\right)$ : a test sample of nickel and $\mathrm{Fe}_{3} \mathrm{O}_{4} \mathrm{NP}(98 \%)$ produced by Nanostructured \& Amorphous Materials Inc., USA. The measurement tolerance of $\sigma_{s}$ did not exceed $2.5 \%$ with respect to the reference sample.

To study the effect of experimental samples on the viability of hepatocellular carcinoma cells of HepG2 line in vitro we used DMEM High glucose (Biowest, France, catalog No. L0102-500), fetal calf serum (FCS) (Biowest, France, catalog No. S181B-500), Versene solution (BioTestLaboratoria, Ukraine), a phosphate-salt buffer (Sigma, USA, Cat No. D1408), a physiological solution (Lekchem, Ukraine, series 71033007), ethyl alcohol (Ukrspirt, Ukraine), a crystalline violet dye (Sigma, USA, Cat No. C6158), plastic dishes for cell culture (TPP, Italy), 96-well cell culture plates (SPL, Korea).

The instruments were used: $\mathrm{CO}_{2}$ incubator (Heal Force, China), an inverted microscope Axiovert 25 (Carl Zeiss, Germany), a Goryaev camera (Farmmedtech, Ukraine), a mini-shaker PSU-2T (BioSan, Latvia), a multi-band spectrophotometer (Labsystems Multiskan PLUS, Finland), automatic pipettes up to $20 \mu \mathrm{l}$ (Eppendorf AG, Germany), $200 \mu \mathrm{l}$ (Thermo Fisher Scientific Oy, Finland) and $1000 \mu 1$ (Eppendorf AG, Germany).

The cells under research were cultured in a complete nutrient medium DMEM with $10 \%$ FTS and $40 \mu \mathrm{g} / \mathrm{mL}$ of gentamicin in plastic dishes in a humidified atmosphere at $5 \% \mathrm{CO}_{2}$ and $37{ }^{\circ} \mathrm{C}$. The medium changes and transitions of the cells were carried out according to the standard method [44]. For the experiments we used cells that were in the exponential phase of growth. After $24-48 \mathrm{~h}$ after the last transition, the cells were planted for cultivation at a concentration of $1-1.5 \times 10^{4}$ cells /well of 96-well cell plate. After $24 \mathrm{~h}$, various amounts of experimental substances were added to the respective wells according to the study scheme and their cytotoxic activity was determined.

The vitality of cells in the experiment was evaluated by means of colorimetric method by colouring cells with crystalline violet. Adhesive cells are separated from the substrate after death. This property is used in order to determine the number of living cells after their treatment with the investigational agents. One of the ways to determine attached (living) cells is to dye them 
with crystalline violet dye which binds to proteins and DNA. The results were evaluated using a multi-spectrophotometer (wave length is $540 \mathrm{~nm}$ ). The percentage of viable cells was calculated according to the formula:

$I_{\mathrm{R}}=(\mathrm{A} 540($ experiment $) / \mathrm{A} 540($ control $)) \times 100 \%$.

The cytotoxic and antiproliferative activity was determined using IC50 indicator.

\section{SYNTHESIS AND PROPERTIES OF MAGNETITE}

The synthesis of nanodisperse magnetite was carried out according to the method [7], by coprecipitation of iron salts according to the reaction:

$$
\mathrm{Fe}^{2+}+2 \mathrm{Fe}^{3+}+8 \mathrm{NH}_{4} \mathrm{OH} \rightarrow \mathrm{Fe}_{3} \mathrm{O}_{4}+4 \mathrm{H}_{2} \mathrm{O}+8 \mathrm{NH}_{4}^{+} .
$$

The synthesized ensembles of $\mathrm{Fe}_{3} \mathrm{O}_{4}$ NP were characterized by dimensions of 3-23 nm. The average size of the NP $\left(d_{0}\right)$ depended on the synthesis conditions and was $6-13 \mathrm{~nm}$, the size distribution could be technologically managed. The specific surface area $\left(S_{s p}\right)$ of synthesized magnetite, dependent on the average particle size, was $S_{s p}=90-180 \mathrm{~m}^{2} / \mathrm{g}$. In this work we used specimens for which $S_{s p}=110 \pm 1 \% \mathrm{~m}^{2} / \mathrm{g}$. The value of mean diameter of the $\mathrm{NP} \mathrm{Fe}_{3} \mathrm{O}_{4}$, calculated from the results of studies of X-ray diffractograms using the Scherrer formula, $D_{X R D}$ was $10.5 \mathrm{~nm}$. Functional $\mathrm{OH}$ groups with concentration of $2.2 \mathrm{mmol} / \mathrm{g}$ were detected in the study of infrared spectra of magnetite surface $[7,14]$.

The synthesized magnetite is characterized by satisfactory magnetic characteristics: the coercivity $H_{\mathrm{c}}=55.0 \pm 2.5 \%$ Oe, the specific magnetization of saturation $\sigma_{\mathrm{s}}=56.2 \pm 2.5 \%$ $\mathrm{Gs} \cdot \mathrm{cm}^{3} / \mathrm{g}$, relative residual magnetization $M_{r} / M_{s}=0.2 \pm 2.5 \%$. Such characteristics are important for medical and biological applications $[7,44]$, for example, while transporting the medicine through blood vessels of small diameter, in which the embolization and aggregation of particles are extremely undesirable.

In $[13,14]$ it has been established that the synthesized magnetite with the given properties is characterized by superparamagnetism of nanoparticles and is in a completely singledomain state. It is known that superparamagnetism is a form of magnetism, which is manifested in ferro- and ferrimagnetic particles.
If such particles are of sufficiently small size, they are converted into a singledomain state, that is, they become homogeneously magnetized through the entire volume at any values and directions of the field $H$. To the peculiarities of the singledomain state of these particles, one can also refer the existence of domains not only in alloys and compounds in the solid state, but also in liquid media (suspensions and colloids).

Adsorption of gemcitabine on a surface of nanosized $\mathrm{Fe}_{3} \mathrm{O}_{4}$. Adsorption of $\mathrm{GC}$ on the surface of magnetite $\mathrm{Fe}_{3} \mathrm{O}_{4}$ was carried out in a medium of saline solution in the range of concentrations $C_{0}=0.02-0.67 \mathrm{mg} / \mathrm{mL}(m=0.03 \mathrm{~g}$, $V=5 \mathrm{~mL}, \mathrm{pH}=3.0$ ) during $2 \mathrm{~h}$ in static mode at room temperature. The $\mathrm{pH}$ of $\mathrm{GC}$ solution medium in $0.9 \% \mathrm{NaCl}$ was given by $0.1 \mathrm{~N} \mathrm{HCl}$.

From the results of researches into the dependence of adsorption activity on $\mathrm{pH}$, the maximal values of $A(\mathrm{mg} / \mathrm{g}), U(\%)$ and $E(\mathrm{~mL} / \mathrm{g})$ for $\mathrm{Fe}_{3} \mathrm{O}_{4}$ are observed in the acid medium at $\mathrm{pH}=3$. According to the results of spectroscopic researches, at the value of $\mathrm{pH}=3$, up to $70 \%$ of GC is in protonated form, which corresponds to the medicinal form of gemcitabine hydrochloride.

The isotherm of adsorption of $\mathrm{GC}$ on the surface of $\mathrm{Fe}_{3} \mathrm{O}_{4}$, and the results of its mathematical processing are given in Fig. 1.

For quantitative description of equilibrium processes in the investigated range of concentrations the Langmuir, Freundlich, and BET [45] models were used. Linearized equations of these models are used to determine the values of the constants (for the Langmuir model $R^{2}=0.849$, the Freundlich -0.996 , BET 0.948 ), included in the isotherm equation.

In our experiments, there has been a deviation in the adsorption character from the Langmuir scheme, which may be caused by the presence of several types of binding centers, characterized by different values of equilibrium constants (energy heterogeneity) and/or the effects of a compatible adsorption. Therefore, we have used the Freundlich model (Fig. $1 a$, Table 1), that describs the isotherm of adsorption on a heterogeneous surface: $A=K_{F} C_{p} 1 / n$, in the linearized form $\ln A=\ln K_{F}+1 / n \ln C$.

The experimental values of the adsorption capacity $A$ were $\sim 37.2 \mathrm{mg} / \mathrm{g}$, the extraction extent $U=33.13 \%$, the separation coefficient $E=82.58 \mathrm{~mL} / \mathrm{g}$ at $C_{0}=0.67 \mathrm{mg} / \mathrm{mL}(m=0.03 \mathrm{~g}$, $V=5 \mathrm{~mL}, \mathrm{pH}=3.0$ ). 
The results of the studies indicate that nanosized magnetite may be promising for the producing of magnetically sensitive adsorption

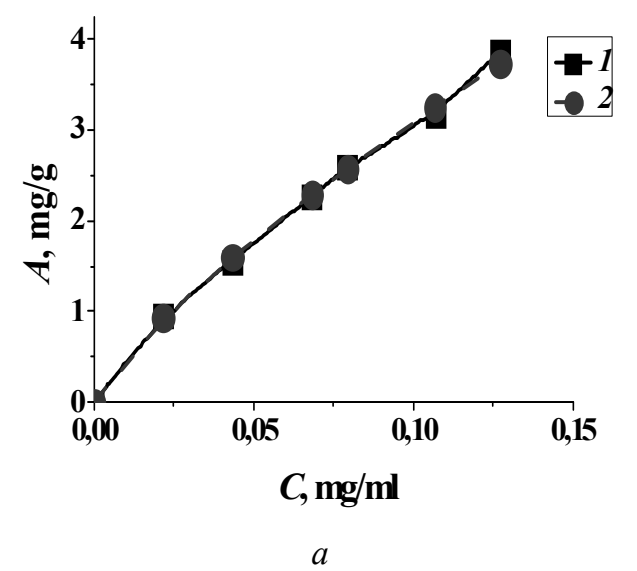

materials for medical purposes, for example, for detoxification of an organism after GC treatment.

Fig. 1. $a$ - Isotherm of adsorption of $\mathrm{GC}$ on surface of $\mathrm{Fe}_{3} \mathrm{O}_{4}(1)$ and that calculated from the Freundlich equation (2); $b$ - the linearized form of the Freundlich isotherm

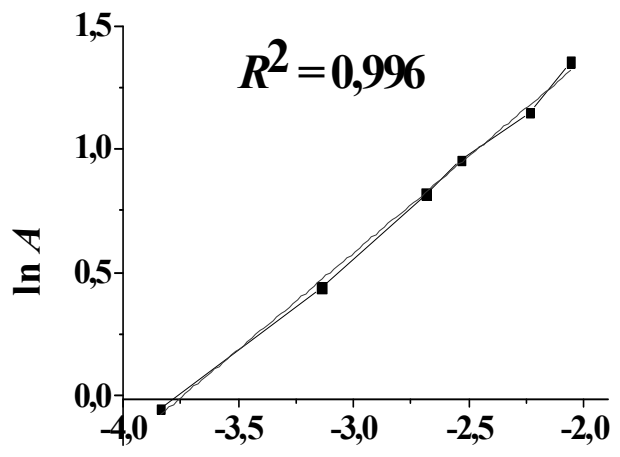

$\ln C$ $b$

Table 1. The data of calculations of the adsorption constants of $\mathrm{GC}$ on $\mathrm{Fe}_{3} \mathrm{O}_{4}$ surface according to Freundlich model

\begin{tabular}{|c|c|c|c|c|c|c|c|}
\hline \multirow{2}{*}{ Surface } & \multicolumn{2}{|c|}{$C, \mathrm{mg} / \mathrm{mL}$} & \multirow{2}{*}{$A_{\text {exp }}, \mathrm{mg} / \mathrm{g}$} & \multicolumn{4}{|c|}{ Freundlich model } \\
\hline & $C_{o}$ & $C_{p}$ & & $A_{\text {calc }}, \mathrm{mg} / \mathrm{g}$ & $\boldsymbol{K}_{F}$ & $n$ & $R^{2}$ \\
\hline $\mathrm{Fe}_{3} \mathrm{O}_{4}$ & 0.15 & 0.12 & 3.87 & 3.72 & 18.7 & 1.28 & 0.996 \\
\hline
\end{tabular}

Magnetic properties of $\mathrm{NCFe}_{3} \mathrm{O}_{4} @ G C$. The magnetic properties of $\mathrm{Fe}_{3} \mathrm{O}_{4} @ \mathrm{GC}$ nanocomposites have been investigated. The measured hysteresis loops of magnetite NP, and $\mathrm{NC}$ with immobilized GC, are shown in Fig. 2 ( $\sigma$ is specific magnetization, $H$ is magnetic field strength). Table 2 shows the magnetic properties of magnetite and $\mathrm{NC}$ with adsorbed gemcitabine derived from experimental hysteresis loops.

In the table: $H_{c}, \mathrm{Oe}$ - coercive force; $\sigma_{s}, \mathrm{emu} / \mathrm{g}$ - specific magnetization of saturation of NC; $\sigma_{r}$, $\mathrm{emu} / \mathrm{g}$ - residual specific magnetization of $\mathrm{NC}$; $\sigma_{r} / \sigma_{s}$ - relative residual magnetization; $\alpha_{\mathrm{Fe} 304}{ }^{\text {calc }}$ calculated mass concentration of $\mathrm{Fe}_{3} \mathrm{O}_{4}$ in $\mathrm{NC}, \%$.

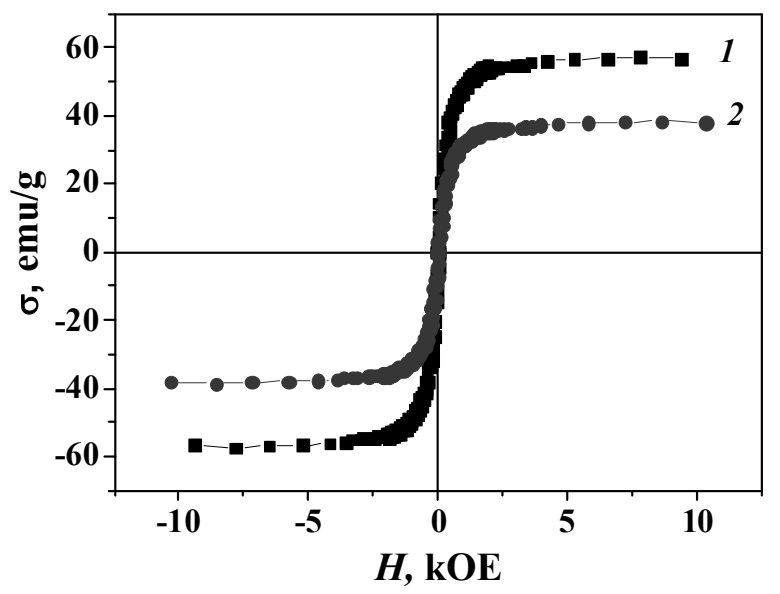

Fig. 2. Hysteresis loops of: 1 - magnetite, 2 - composite $\mathrm{Fe}_{3} \mathrm{O}_{4} @$ GC. $T=300 \mathrm{~K}$ 
Table 2. Magnetic characteristics of magnetite and NC with adsorbed GC

\begin{tabular}{cccccc}
\hline Sample & $\boldsymbol{H}_{\boldsymbol{c}}, \mathbf{O e}$ & $\boldsymbol{\sigma}_{\boldsymbol{s}}, \mathbf{e m u} / \mathbf{g}$ & $\boldsymbol{\sigma}_{\boldsymbol{r}}, \mathbf{e m u} / \mathbf{g}$ & $\boldsymbol{\sigma}_{\boldsymbol{r}} / \boldsymbol{\sigma}_{\boldsymbol{s}}$ & $\boldsymbol{\alpha}_{\mathrm{Fe304}}{ }^{\text {calc }}, \boldsymbol{\%}$ \\
\hline $\mathrm{Fe}_{3} \mathrm{O}_{4}$ & 41 & 57.7 & 10.4 & 0.18 & 100 \\
$\mathrm{Fe}_{3} \mathrm{O}_{4} @ \mathrm{GC}$ & 44 & 39.0 & 6.07 & 0.15 & 68 \\
\hline
\end{tabular}

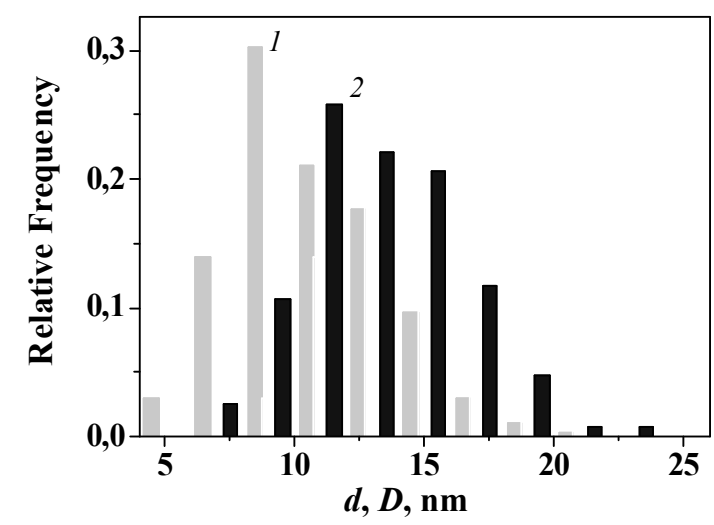

Fig. 3. Histograms of relative frequencies of the diameters of $\mathrm{NP} \mathrm{Fe}_{3} \mathrm{O}_{4}$ and $\mathrm{NC} \mathrm{Fe}_{3} \mathrm{O}_{4} @ \mathrm{GC},(d, D$, respectively)

The histograms of the relative frequencies of the diameters of $\mathrm{NPFe}_{3} \mathrm{O}_{4} d$ and $\mathrm{NCFe}_{3} \mathrm{O}_{4} @ \mathrm{GC}$ $D(1,2$, respectively) were constructed (Fig. 3) using the method of magnetic granulometry and assuming that the thickness of $\mathrm{GC}$ layers depends hardly on the diameter of $\mathrm{NP} \mathrm{Fe}_{3} \mathrm{O}_{4}$.

The obtained results are typical for coreshell type structures. The average value of the thickness of the adsorbed layer of GC in the composition of $\mathrm{NC} \mathrm{Fe}_{3} \mathrm{O}_{4} @ \mathrm{GC}$ is $2.4 \pm 0.1 \mathrm{~nm}$, as evaluated by the method of magnetic granulometry.

Synthesis and properties of magnetic liquids. Magnetic liquids (ML) based on magnetite and physiological solution (PS) stabilized with sodium oleate (Ol.Na) and polyethylene glycol (PEG) containing GC $\left(\mathrm{Fe}_{3} \mathrm{O}_{4} @ \mathrm{GC} / \mathrm{Ol} . \mathrm{Na} / \mathrm{PEG}+\mathrm{PS}\right)$ were synthesized.

PS was used as the dispersion medium of samples of magnetic liquids for research. It should be noted, that the use of distilled water as dispersion medium, does not change the magnetic properties of colloidal systems substantially.

Nanosized magnetite was used as a dispersed phase, in the singledomain state, or related NC $\mathrm{Fe}_{3} \mathrm{O}_{4} @ \mathrm{GC}$.

To prevent aggregation, $\mathrm{Fe}_{3} \mathrm{O}_{4}$ nanoparticles and $\mathrm{NC}$ were stabilized with sodium oleate $\left(\mathrm{C}_{8} \mathrm{H}_{17} \mathrm{CH}=\mathrm{CH}\left(\mathrm{CH}_{2}\right)_{7} \mathrm{CO}-\mathrm{O}-\mathrm{Na}\right)$, (dynamic mode, $1 \mathrm{~h}$ ) and polyethylene glycol (PEG-2000).

The mass of sodium oleate $m_{\mathrm{Ol} . \mathrm{Na}}$ used to stabilize the surface of the NP and NC in the composition of the ML was calculated taking into account the concentration of hydroxyl groups on the surface of magnetite. The calculation was made using the formula: $m_{\mathrm{Ol} . \mathrm{Na}}=B \cdot M \cdot m$, where $B$ is the concentration of hydroxyl groups $(2.2 \mathrm{mmol} / \mathrm{g})$ on the surface of starting nanosized magnetite, $M$ - molecular weight of sodium oleate $(304 \mathrm{~g} / \mathrm{mol}), m$ is the mass of $\mathrm{Fe}_{3} \mathrm{O}_{4}$ or NC.

It is known that PEG interferes with adsorption interactions of liquid components with protein molecules [45], which is important for medical applications of magnetic liquids. Additional modification with PEG-2000 was carried out in a dynamic mode using a shaker, the amount of polymer was $10-15 \%$ of the weight of the bulk of NP $\mathrm{Fe}_{3} \mathrm{O}_{4}$, or NC $[13,14]$.

Fig. 4 shows the hysteresis loops of aqueous $\mathrm{ML} \mathrm{Fe}_{3} \mathrm{O}_{4} @ \mathrm{O}$.Na/PEG+PS (1) and $\mathrm{Fe}_{3} \mathrm{O}_{4} @ G C / O 1 . N a / P E G+P S$ (2). The thickness of the layer of GC is $\sim 2.3 \mathrm{~nm}$. The thickness of the layer of the stabilizer $\sim 3 \mathrm{~nm}$, and the volumes of water in the ML are the same.

As known, taking into account the distribution of nanocomposite particles by volumes $p(V)$, the magnetization curve of $\mathrm{ML}$ (Fig. 5) can be represented as follows [46]:

$$
M(H)=\varphi_{\rho} \int_{0}^{\infty} p(v) v^{-1}\left[M_{s} v_{c} L(x)+\chi v_{s} H\right] d v
$$


where $\varphi_{\rho}$ is the volume fraction of the magnetic component in ML, determined by its density, $p(v)=\frac{1}{v \sigma_{\ln v} \sqrt{2 \pi}} \cdot \exp \left[-\ln ^{2}\left(v / v_{m}\right) /\left(2 \sigma_{\ln v}^{2}\right)\right]$ $v$ - volume of a NC particle, $M_{s}$ - magnetization of the saturation of the core, $v_{\mathrm{c}}-$ volume of the core, $L(x)=c t h x-x^{-1}-$ Langevin's function, $x=\left(M_{s} v_{c} H / k_{B} T\right), \chi-$ magnetic susceptibility of the shell, $v_{s}-$ shell volume. The main contribution to the magnetization of $\mathrm{ML}$ is introduced by the superparamagnetism of the cores and the paramagnetism of the shells of the core@shell particles. Compared to superparamagnetism of cores in the fields $H=0-10 \mathrm{kOe}$, in most cases the paramagnetism of the shells (the second term in (1)) can be neglected.

The modification of ML $\mathrm{Fe}_{3} \mathrm{O}_{4} @ \mathrm{GC} / \mathrm{Ol}$.Na/PEG+PS with AB HER2 (receiving ML $\mathrm{Fe}_{3} \mathrm{O}_{4} @ \mathrm{GC} / \mathrm{Ol}$.Na/PEG/AB HER2+PS) was performed dynamically with use of a shaker.

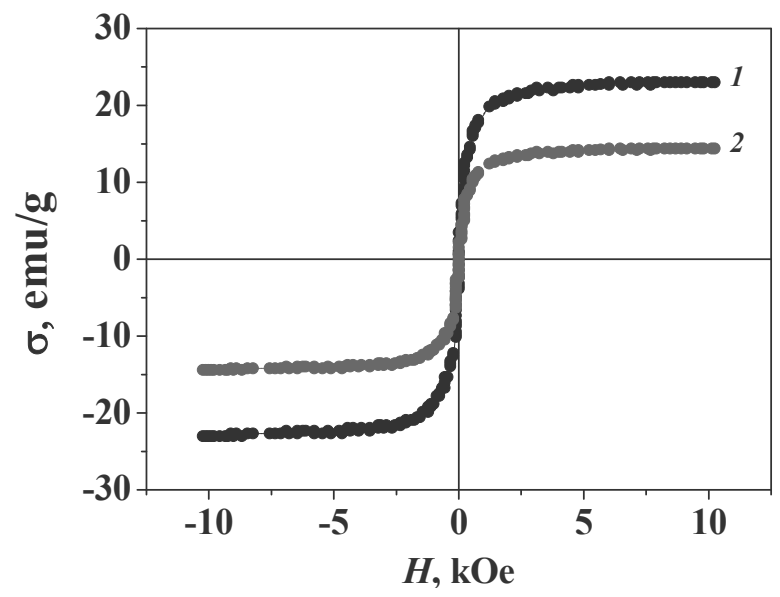

Fig. 4. Hysteresis loops of aqueous $\mathrm{ML} \mathrm{Fe}_{3} \mathrm{O}_{4} @ \mathrm{Ol}$.Na/PEG+PS (thickness of the stabilizer layer $\left.\sim 3 \mathrm{~nm}\right)(1)$ and $\mathrm{Fe}_{3} \mathrm{O}_{4} @ \mathrm{GC} / \mathrm{Ol} . \mathrm{Na} / \mathrm{PEG}+\mathrm{PS}(2)$

The optimal parameters of the experimental ML on the basis of magnetite were evaluated: concentration of $\mathrm{Fe}_{3} \mathrm{O}_{4}-14 \mathrm{mg} / \mathrm{mL}$, size of $\mathrm{Fe}_{3} \mathrm{O}_{4}$ particles - 4-22 nm, average size of $\mathrm{Fe}_{3} \mathrm{O}_{4}$ particles $-10.8 \mathrm{~nm}$; the average size of $\mathrm{Fe}_{3} \mathrm{O}_{4}$ particles stabilized with sodium oleate $-16.8 \mathrm{~nm}$; saturation magnetization $M_{\infty}=14.1 \pm 2.5 \%$ Gs, hypsometric height $-25 \pm 10 \% \mathrm{~cm}$, viscosity $\eta=1.14 \pm 3 \% \mathrm{mPa} \cdot \mathrm{s}, \quad$ density $\quad \rho_{\mathrm{ML}}=1.14 \pm$ $1.0 \% \mathrm{~g} / \mathrm{cm}^{3}$, the concentration of $\mathrm{GC}$ was $1.25 \mathrm{mg} / \mathrm{mL}$, HER $2 \mathrm{AB}-3.75 \mu \mathrm{g} / \mathrm{mL}$.

The concentration of GC and AB HER2 in such ML is determined by the therapeutic necessity. In the starting ML, the concentration of GC and AB HER2 has been $1.25 \mathrm{mg} / \mathrm{mL}$ and $3.75 \mu \mathrm{g} / \mathrm{mL}$, respectively, which allows one providing the necessary dosages of the medicine in the experimental samples by diluting the initial ML. In addition, such a liquid is characterized by satisfactory rheological properties and sedimentation resistance.
Investigation of influence of experimental samples on viability of HepG2 hepatocellular carcinoma cells of human liver in vitro. For the research, the series of experimental samples were used:

1. ML: $\mathrm{Fe}_{3} \mathrm{O}_{4} @ \mathrm{O}$.Na/PEG+PS (control 1),

2. Gemcitabine (control 2),

3. AB HER2 (control 3),

4. $\mathrm{ML}+\mathrm{GC}: \mathrm{Fe}_{3} \mathrm{O}_{4} @ \mathrm{GC} / \mathrm{Ol} . \mathrm{Na} / \mathrm{PEG}+\mathrm{PS}$,

5. $\mathrm{ML}+\mathrm{AB}: \mathrm{Fe}_{3} \mathrm{O}_{4} @ \mathrm{Ol}$.Na/PEG+PS+HER2,

6. $\mathrm{ML}+\mathrm{GC}+\mathrm{AB}: \mathrm{Fe}_{3} \mathrm{O}_{4} @ \mathrm{GC} / \mathrm{Ol} . \mathrm{Na} / \mathrm{PEG}+\mathrm{PS}$

+ HER2,

7. GC + HER2 (control 4),

8. PS (control 5).

The concentration of magnetite for all systems was $C_{\mathrm{Fe} 304}=3 \mathrm{mg} / \mathrm{mL}$, the concentration of gemcitabine $C_{\mathrm{GC}}=0.25 \mathrm{mg} / \mathrm{mL}$, that of antibody $C_{\mathrm{AB}}=0.75 \mu \mathrm{g} / \mathrm{mL}$.

According to the results of research into the influence of experimental samples on the viability of HCC cells of human liver of HepG2 
line, features were revealed of the influence of the composite system $\mathrm{ML}+\mathrm{GC}+\mathrm{AB}$ $\left(\mathrm{Fe}_{3} \mathrm{O}_{4} @ \mathrm{GC} / \mathrm{Ol} . \mathrm{Na} / \mathrm{PEG}+\mathrm{PS}+\mathrm{HER} 2\right)$ and of each component separately (ML, GC, AB, PS, respectively) on $\mathrm{HCC}$ cells.

In particular:

1. IC50 for ML was $0.155 \mathrm{mg} / \mathrm{mL}$ (control 1). In samples with a ML concentration more than $0.19 \mathrm{mg} / \mathrm{mL}$, the number of living cells is not determined, which is, likely, due to high optical density of samples.

2. The HER2 AB in monoapplication (control 3) in the studied concentrations does not affect the viability or proliferation of hepatocellular carcinoma of human liver cells of the HepG2 line, as its effect does not decrease the cell viability and does not differ practically from the influence of PS (control 5).

3. The cultivation of HepG2 cells at the same time in the presence of ML and AB HER2 at concentrations less than $0.05 \mathrm{mg} / \mathrm{mL}$ and $0.013 \mu \mathrm{g} / \mathrm{mL}$, respectively, did not practically affect the viability of cells of liver carcinoma. However, the complex application of ML and HER 2 at concentrations of $0.1 \mathrm{mg} / \mathrm{mL}$ and $0.025 \mu \mathrm{g} / \mathrm{mL}$, respectively, reduced the number of viable cells of the said line to $\sim 85.9 \%$.

4. IC50 for GC was $0.002 \mathrm{mg} / \mathrm{mL}$ (control 2). The influence of GC in monoapplication at the concentration of $0.008 \mathrm{mg} / \mathrm{mL}$ left $\sim 78 \%$ of cells in a viable state. The use of GC in this concentration in combination with ML $(0.1 \mathrm{mg} / \mathrm{mL})$ showed a synergistic effect and increased the effectiveness of cytostatic drug up to $\sim 10 \%$ (the number of alive cells was $\sim 68 \%$ ).

5. The combined application of $\mathrm{GC}$ and $\mathrm{AB}$ HER2 (control 4) at concentrations of $0.008 \mathrm{mg} / \mathrm{mL}$ and $0.025 \mu \mathrm{g} / \mathrm{mL}$, respectively, also showed a synergistic effect, that resulted in a decrease of number of viable cells to $\sim 65 \%$.

6. The use of a composite system consisting of GC and HER2 at concentrations of $0.008 \mathrm{mg} / \mathrm{mL}$ and $0.025 \mu \mathrm{g} / \mathrm{mL}$, respectively, and $\mathrm{ML}\left(0.1 \mathrm{mg} / \mathrm{mL}\right.$ with respect to $\left.\mathrm{Fe}_{3} \mathrm{O}_{4}\right)$ results in a reduction of the number of viable cells of HepG2 liver carcinoma to $\sim 55 \%$, that indicates a significant synergistic effect of the said components.

The revealed synergistic cytotoxic/cytostatic effect can be explained by the high biological activity of the complex $\mathrm{Fe}_{3} \mathrm{O}_{4}$-GC-HER2 with the integrated ligand due to recognition of HepG2 tumor cell receptors and pharmacological correction of endogenous iron exchange, which is ensured by the use of iron-containing ML, GC, and HER2 antibodies.

Indeed, in mechanisms of implementation of the apoptosis program due to formation of the medicinal effect of $\mathrm{NC}$, violations of the exchange of endogenous iron in tumor cells play an essential role [47]. The said violations cause an increased need of iron for cells, which is satisfied by the accumulation of a significant number of $\mathrm{Fe}_{3} \mathrm{O}_{4}$ nanoparticles with ML. The high level of "free iron" in the form of accumulated $\mathrm{Fe}_{3} \mathrm{O}_{4}$ and acidic medium in the cells, causes accelerated formation of iron ions and active forms of oxygen (Fenton reaction), which in its turn, leads to oxidative stress of cells and apoptosis. Thereby an increase occurs also in the effectiveness of both GC and HER2 AB. As an example we can take the increase up to $\sim 10 \%$ in the action of $\mathrm{GC}$ at the concentration of $0.008 \mathrm{mg} / \mathrm{mL}$ in the composition of ML and the appearance of cytotoxic action of the ML+ HER2 complex at a level of $\sim 10 \%$ at the concentration of HER2 of $0.025 \mu \mathrm{g} / \mathrm{mL}$, compared to the absence of activity of $\mathrm{AB}$ in these doses in monoapplication.

Thus, the combined effect of ML, GC, and HER2 on the HepG2 cells significantly exceeds their effects in monouse at the same concentrations, which results in synergistic effect.

So, in vitro, an example of the effect of a new magnetocarried colloidal system, containing magnetite, antitumor component GC and HER2 antibody, on HCC human liver cells of HepG2 line shows the possibility to achieve a cytotoxic effect at substantially lower concentrations of chemo- and immunotherapeutic medicines and to create conditions for reducing of toxico-allergic reactions of the organism as a whole. In addition, the revealed experimental data indicate that the investigated MLs can be promising for use in the method of targeted delivery and local therapy of oncological diseases.

\section{CONCLUSION}

The processes of adsorption of $\mathrm{GC}$ on the surface of nanosized singledomain magnetite $\left(\mathrm{Fe}_{3} \mathrm{O}_{4}\right)$ have been studied. In the experiment, the value of the adsorption capacity $A$ reached 
$\sim 37.2 \mathrm{mg} / \mathrm{g}$, the extraction extent $U=33.13 \%$, the separation factor $E=82.58 \mathrm{~mL} / \mathrm{g}$. The adsorption matching to the Freundlich model has been established.

The $\mathrm{NC} \mathrm{Fe}_{3} \mathrm{O}_{4} @ \mathrm{GC}$ were synthesized and their magnetic properties were investigated. The average value of the thickness of the adsorbed layer GC $(2.4 \pm 0.1 \mathrm{~nm})$ in the $\mathrm{NC} \mathrm{Fe}_{3} \mathrm{O}_{4} @ \mathrm{GC}$ was evaluated through the method of magnetic granulometry.

The ML were synthesized based on magnetite and PS, stabilized with Ol.Na and PEG, containing $\mathrm{GC}$ and HER2 AB $\left(\mathrm{Fe}_{3} \mathrm{O}_{4} @ \mathrm{GC} / \mathrm{Ol} . \mathrm{Na} / \mathrm{PEG}+\mathrm{PS}\right)$. The properties of ML were studied as well as cytotoxic/cytostatic activity in relation to $\mathrm{HCC}$ of human liver of HepG2 line.

The obtained data can be useful for predicting of the nanoscale architecture of magnetically sensitive $\mathrm{NC}$ and $\mathrm{ML}$ in the production of medicines on their basis.

The synergistic nature of the effect of $\mathrm{GC} / \mathrm{Fe}_{3} \mathrm{O}_{4} / \mathrm{HER} 2$ complex on HepG2 cells was revealed. It has been shown that HER2 AB alone does not affect HepG2 cell viability/ proliferation in investigated concentrations.

GC suppressed cell proliferation of liver carcinoma, the IC50 value was $0.002 \mathrm{mg} / \mathrm{mL}$ in vitro. The use of ML in combination with GC can increase the cytotoxic activity of the composite up to $8-10 \%$. The ML + GC + HER2 complexes caused a synergistic effect and increased the cytotoxic activity, compared with GC in monouse, to $18-20 \%$, while GC content reduced to $0.008 \mathrm{mg} / \mathrm{mL}$.

The results of the studies indicate that the use of ML on the basis of magnetite, gemcitabine and antibody increases the effectiveness of the antitumor medicines with a significant reduction in their dose and, respectively, the toxico-allergic reactions of the body, and nanosized magnetite may be promising for the manufacture of magnetically sensitive adsorption materials for medical purposes, for example, detoxification of an organism after GC therapy.

\title{
Магніточутливі нанокомпозити та магнітні рідини на основі магнетиту, гемцитабіну і антитіла HER2
}

\author{
А.Л. Петрановська, М.В. Абрамов, Н.М. Опанащук, С.П. Туранська, \\ П.П. Горбик, Н.В. Кусяк, А.П. Кусяк, Н.Ю. Лук'янова, В.Ф. Чехун \\ Інститут хімії поверхні ім. О.О. Чуйка Національної академії наук Украӥни \\ вул. Генерала Наумова, 17, Київ, 03164, Україна, phorbyk@ukr.net \\ Житомирський державний університет імені Івана Франка \\ вул. В. Бердичівська, 40, Житомир, 10008, Украӥна \\ Інститут експериментальної патологї̈, онкології та радіобіологї̈ ім. Р.С. Кавецького \\ Національної академії наук України \\ вул. Васильківська, 45, Київ, 03022, Украӥна
}

\begin{abstract}
Досліджено проиеси адсорбиї гемичтабіну (ГЦ) на поверхні нанорозмірного однодоменного магнетиту $\left(\mathrm{Fe}_{3} \mathrm{O}_{4}\right)$. В умовах експерименту значення адсорбційної ємності А становило 37.2 мг/2, ступінь вилучення $U=33.13 \%$, коефіиієнт розділення $E=82.58$ мл/2. Встановлено відповідність адсорбиї моделі Фрейндліха. Досліджено магнітні властивості нанокомпозитів (НК) $\mathrm{Fe}_{3} \mathrm{O}_{4} @ \Gamma Ц$. Методом магнітної гранулометрії оцінено середнє значення товщини адсорбованого шару ГЦ у складі $\mathrm{HK} \mathrm{Fe}_{3} \mathrm{O}_{4} @ \Gamma Ц$, яке становить $2.4 \pm 0.1$ нм. Синтезовано магнітні рідини (МР) на основі магнетиту $i$ фізіологічного розчину (ФР), стабілізовані олеатом натрію (Ol.Na) і поліетиленгліколем (PEG), що містять ГЦ та антитіло (AT) HER2 $\left(\mathrm{Fe}_{3} \mathrm{O}_{4} @ \Gamma Ц / \mathrm{Ol} . \mathrm{Na} / \mathrm{PEG}+\Phi \mathrm{P}\right)$. Досліджено властивості MP та цичтотоксичну/цитостатичну активність щзодо гепатоиелюлярної карииноми (ГЦК) печінки людини лінії НерG2. Встановлено параметри MP на основі магнетиту: концентрація $\mathrm{Fe}_{3} \mathrm{O}_{4}-14$ мг/мл, розмір частинок $\mathrm{Fe}_{3} \mathrm{O}_{4}-4-22 \mathrm{\mu м}$, середній розмір частинок $\mathrm{Fe}_{3} \mathrm{O}_{4}-10.8$ нм; середній розмір частинок $\mathrm{Fe}_{3} \mathrm{O}_{4}$, стабілізованих олеатом натрію - 16.8 нм; намагніченість насичення $M_{\infty}=14.1 \pm 2.5 \%$ Гс, гіпсометрична висота $-25 \pm 10 \%$ см, в'язкість $\eta=1.14 \pm 3 \%$ мПа с, густина $\rho_{\text {мР }}=1.14 \pm 1.0 \%$ г $/ \mathrm{cm}^{3}$, концеентрація ГЦ становила 1.25 мг/мл, АT HЕR2 - 3.75 мкг/мл. Отримані розрахункові та графічні дані щзодо залежності питомої площі поверхні $i$ питомої намагніченості
\end{abstract}


насичення $\mathrm{HK} \mathrm{Fe}_{3} \mathrm{O}_{4} @$ @Ц/Ol.Na/PEG від товщини шару ГЦ можуть бути корисними для прогнозування наноархітектури магніточутливих НК і МР при виготовленні лікарських засобів на їхній основі. Виявлено синергічний характер ефекту впливу комплексу ГЦ/Fe $\mathrm{O}_{4} / \mathrm{HER2}$ на клітини НерG2. Встановлено, щзо IC50 для MP становить 0.155 мг/мл, у діапазоні концентрацій 0.025-0.1 мг/мл МР є біосумісною з клітинами НерG2. Показано, щзо AT HER2 у монозастосуванні в досліджених концентраціях не впливає на життєздатність/проліферацію клітин НерG2. ГЦ пригнічує проліферацію клітин карциноми печінки, значення IC50 становило 0.002 мг/мл in vitro. Використання МР в комплексі з ГЦ дозволяє підвищити циитотоксичну активність композиту на 8-10\%. Комплекси МР+ГЦ+АТ НЕR2 спричиняли синергічний ефект та підвищення циитотоксичної активності, порівняно з ГЦ у монозастосуванні, до 18-20\%, при цъьому вміст ГЦ змениувався до 0.008 мг/мл.

Результати досліджень свідчать, щзо використання МР на основі магнетиту, гемциттабіну та антитіла підвищує ефективність дії протипухлинних препаратів при істотному зменшенні їх дози та, відповідно, токсико-алергічних реакцій організму, а нанорозмірний магнетит може бути перспективним для виготовлення магніточутливих адсорбчійних матеріалів медичного призначення, наприклад, для детоксикаиії організму після терапії ГЦ.

Ключові слова: магнетит, магнітна рідина, геми̧итабін, антитіло HER2, гепатоичелюлярна карцинома печінки людини

\title{
Магниточувствительные нанокомпозиты и магнитные жидкости на основе магнетита, гемцитабина и антитела HER2
}

\author{
А.Л. Петрановская, Н.В. Абрамов, Н.М. Опанащук, С.П. Туранская, \\ П.П. Горбик, Н.В. Кусяк, А.П. Кусяк, Н.Ю. Лукьянова, В.Ф. Чехун
}

\author{
Институт химии поверхности им. А.А. Чуйко Наџиональной академии наук Украинь \\ ул. Генерала Наумова, 17, Киев, 03164, Украина, phorbyk@ukr.net \\ Житомирский государственный университет им. Ивана Франко \\ ул. Б. Бердичевская, 40, Житомир, 10008, Украина \\ Институт экспериментальной патологии, онкологии и радиобиологии им. Р.Е. Кавецякого \\ Национальной академии наук Украины \\ ул. Васильковская, 45, Киев, 03022, Украина
}

\begin{abstract}
Исследованы процессы адсорбиии гемичтабина (ГЦ) на поверхности наноразмерного однодоменного магнетита $\left(\mathrm{Fe}_{3} \mathrm{O}_{4}\right)$. В условиях эксперимента значение адсорбичонной емкости А составило 237.2 мг/2, степень извлечения $U=33.13 \%$, коэффициент разделения $E=82.58$ мл/2. Установлено соответствие адсорбиии модели Фрейндлиха. Исследованы магнитные свойства нанокомпозитов (HK) $\mathrm{Fe}_{3} \mathrm{O}_{4} @ \Gamma Ц$. Методом магнитной гранулометрии оценено среднее значение толщины адсорбированного слоя ГЦ в

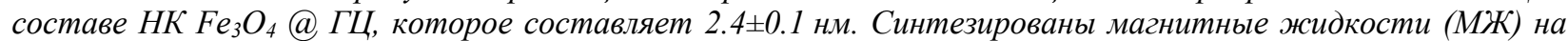
основе магнетита и физиологического раствора (ФР), стабилизированные олеатом натрия (Ol.Na) $u$ полиэтиленгликолем (PEG), содержащие ГЦ и антитело (AT) HER2 (Fe $\left.\mathrm{O}_{4} @ \Gamma Ц / O l . N a / P E G+\Phi P\right)$. Исследованы свойства МЖ и циитотоксическое/цитостатическое действие в отнотении гепаточеллюлярной карииномы (ГЦК) печени человека линии НерG2. Установлены параметры МЖ на основе магнетита: концентрация $\mathrm{Fe}_{3} \mathrm{O}_{4}-14$ мг/мл, размер частии $\mathrm{Fe}_{3} \mathrm{O}_{4}-4-22$ нм, средний размер частиц $\mathrm{Fe}_{3} \mathrm{O}_{4}$ - 10.8 нм; средний размер частии $\mathrm{Fe}_{3} \mathrm{O}_{4}$, стабилизированных олеатом натрия - 16.8 нм; намагниченность насыщения $M_{\infty}=14.1 \pm 2.5 \%$ Гс, гипсометрическая высота - $25 \pm 10 \% \mathrm{cм}$, вязкость $\eta=1.14 \pm 3 \%$ мПа с, плотность $\rho_{\text {мж }}=1.14 \pm 1.0 \%$ г $/ \mathrm{cm}^{3}$, концентрация ГЦ составила 1.25 мг/мл, АТ НЕR2 3.75 мкг/мл. Полученные расчетные и графические данные о зависимости удельной площяади поверхности и удельной намагниченности насыщения $\mathrm{HK} \mathrm{Fe}_{3} \mathrm{O}_{4} @$ @ЦL/Ol.Na/PEG от толщины слоя ГЦ могут быть полезными для прогнозирования наноархитектуры магниточувствительных НК и МЖ при изготовлении лекарственных средств на их основе. Выявлено синергический характер эффекта воздействия комплекса ГЦ/Fe $\mathrm{O}_{4} / \mathrm{HER} 2$ на клетки НерG2. Установлено, что IC50 для МЖ составляет 0.155 мг/мл, в диапазоне концентраций 0.025-0.1 мг/мл МЖ характеризуется биосовместимостью с клетками НерG2. Показано, что AT HER2 при моноиспользовании в исследованных концентрациях не влияет на жизнеспособность / пролиферацию клеток НерG2. ГЦ подавляет пролиферацию клеток карииномы печени, значение IC50
\end{abstract}


составляло 0.002 мг/мл іn vitro. Использование МЖ в комплексе с ГЦ позволяет повысить ичитотоксическую активность композита на 8-10\%. Комплексы МЖ + ГЦ + АТ HER2 вызывали синергический эффект и повышение ичитотоксической активности, по сравнению с ГЦ в моноприменении, до 18-20\%, при этом содержание ГЦ уменьшалось до 0.008 мг/мл.

Результать исследований свидетельствуют, что использование МЖ на основе магнетита, гемцитабина и антитела повышает эффективность действия противоопухолевых препаратов при существенном уменьшении их дозы и, соответственно, токсико-аллергических реакций организма, а наноразмерный магнетит может быть перспективным для изготовления магниточувствительных адсорбционных материалов медициского назначения, например, для детоксикачии организма после терапии ГЦ.

Ключевые слова: магнетит, магнитная жидкость, гемцитабин, антитело НЕR2, гепатоцеллюлярная карцинома печени человека

\section{REFERENCES}

1. Roco M.C., Williams R.S. Vision for Nanotechnology R\&D in the Next Decade. Alivisatos. 2002. 156: 171.

2. Levy L., Sahoo Y., Earl B.J. Synthesis and characterization of multifunctional nanoclinics for biological applications. Chem. Mater. 2002. 14(8): 3715.

3. Lund K., Manzo A.J., Dabby N., Michelotti N., Johnson-Buck A., Nangreave J., Taylor S., Pei R., Stojanovic M.N., Walter N.G., Winfree E., Yan H. Molecular robots guided by prescriptive landscapes. Nature. 2010. 465(7295): 206.

4. $\quad$ Muscat R.A., Bath J., Turberfield. A.J. Programmable molecular robot. Nanoletters. 2011. 11(3): 982.

5. Shpak A.P., Gorbyk P.P. Physical chemistry of nanomaterials and supramolecular structures. (Kyiv: Naukova dumka, 2007). [In Russian].

6. Shpak A.P., Gorbyk P.P. Nanomaterials and Supramolecular Structures: Physics Chemistry and Applications. (Nederlands: Springer, 2009.)

7. Gorbyk P.P. Nanocomposites with functions of biomedical nanorobots: synthesis, properties, applications. Nanosystems, nanomaterials, nanotechnologies. 2013. 11(2): 323. [In Ukrainian].

8. Patent UA 99211. Gorbyk P.P., Petanovskaya A.L., Turelik M.P., Korduban A.M., Shpak A.P., Chekhun V.F., Turanska S.P., Vasilieva O.A., Lukyanova N. Nanocapsule with functions of nanorobot. 2012.

9. Abramov M.V., Kusyak A.P., Kaminskiy O.M., Turanska S.P., Petranovska A.L., Kusyak N.V., Gorbyk P.P. Magnetosensitive Nanocomposites Based on Cisplatin and Doxorubicin for Application in Oncology. Horizons in World Physics. 2017. 292: 1.

10. Pylypchuk V., Kolodynska D., Gorbyk P.P. Gd(III) adsorption on the DTPA-functionalized chitosan/magnetite nanocomposites. Sep. Sci. Technol. 2018. 53(7): 1006.

11. Gorbyk P.P., Lerman L.B., Petranovska A.L., Turanska S.P. Magnetosensitive Nanocomposites with Functions of Medico-Biological Nanorobots: synthesis and properties. In: Advances in Semiconductor Research: Physics of Nanosystems, Spintronics and Technological Applications. 2014. P. 161.

12. Gorbyk P.P., Lerman L.B, Petranovska A.L., Turanska S.P., Pylypchuk I.V. Magnetosensitive Nanocomposites with Hierarchical Nanoarchitecture as Biomedical Nanorobots: synthesis, properties and application. Fabrication and Self-Assembly of Nanobiomaterials, Applications of Nanobiomaterials. 2016. 1: 289.

13. Petranovska A.L., Abramov N.V., Turanska S.P., Gorbyk P.P., Kaminskiy A.N., Kusyak N.V. Adsorption of cisdichlorodiammineplatinum by nanostructures based on single-domain magnetite. J. Nanostruct. Chem. 2015. 5(3): 275.

14. Abramov N.V., Turanska S.P., Kusyak A.P., Petranovska A.L., Gorbyk P.P. Synthesis and properties of magnetite/hydroxyapatite/doxorubicin nanocomposites and magnetic fluids based on them. J. Nanostruct. Chem. 2016. 6(3): 223.

15. Gorbyk P.P., Chekhun V.F. Nanocomposites of Medicobiologic Destination: reality and perspectives for oncology. Functional Materials. 2012. 19(2): 145.

16. Pylypchuk I.V., Abramov M.V., Petranovska A.L., Turanksa, S.P., Budnyak T.M., Kusyak N.V., Gorbyk P.P. Multifunctional Magnetic Nanocomposites on the Base of Magnetite and Hydroxyapatite for Oncology. In book International Conference on Nanotechnology and Nanomaterials. (Springer, 2017). P. 35.

17. Abramov M.V., Turanskaya S.P., Gorbyk P.P. Magnetic properties of nanocomposites of the superparamagnetic kernel-shell type. Metallofizika i Noveishie Tekhnologii. 2018. 40(4): 423. [In Ukrainian]. 
18. Abramov M.V., Turanskaya S.P., Gorbyk P.P. Magnetic properties of liquids based on polyfunctional nanocomposites such as superparamagnetic core - multilevel shell. Metalloys. the latest technol. Metallofizika $i$ Noveishie Tekhnologii. 2018. 40(10): 1283. [In Ukrainian].

19. Pylypchuk V., Kołodyńska D., Kozioł M., Gorbyk P.P. Gd-DTPA Adsorption on Chitosan/Magnetite Nanocomposites. Nanoscale Res. Lett. 2016. 11(1):168.

20. Patent UA 112490 Chekhun V.F., Lukyanova N.Y., Gorbyk P.P., Todor I.M., Petranovskaya A.L., Boshitskaya N.V., Bozhko I.V. Antitumor ferromagnetic nanocomposite. 2016.

21. Gorbyk P.P, Petranovska A.L., Turelyk M.P., Abramov N.V., Chekhun V.F., Lukyanova N.Yu. Construction of magnetocarried nanocomposites for medico-biological applications. Him. Fiz. Tehnol. Poverhni. 2010. 1(3): 360.

22. Gorbyk P.P., Dubrovin I.V., Petranovskaya A.L., Turelik M.P. Magnetically controlled transport of medicines: current state of development and prospects. Surface. 2010. 2(17): 287. [In Russian].

23. Gorbyk P.P., Petranovskaya A.L., Turelik M.P., Abramov N.V., Turanska S.P, Pilipchuk E.V., Chekhun V.F., Lukyanova N.Yu., Shpak A.P., Korduban A.M. Problem on directed drug transport: current status and prospects. Him. Fiz. Tehnol. Poverhni. 2011. 2(4): 461. [In Russian].

24. Kang T.W., Yevsa T., Woller N., Hoenicke L., Wuestefeld T., Dauch D., Hohmeyer A., Gereke M., Rudalska R., Potapova A., Iken M., Vucur M., Weiss S., Heikenwalder M., Khan S., Gil J., Bruder D., Manns M., Schirmacher P., Tacke F., Ott M., Luedde T., Longerich T., Kubicka S., Zender L. Senescence surveillance of premalignant hepatocytes limits liver cancer development. Nature. 2011. 479(7374): 547.

25. Yevsa T., Kang T.W., Zender L. Immune surveillance of pre-cancerous senescent hepatocytes limits hepatocellular carcinoma development. Oncoimmunology. 2012. 1(3): 398.

26. Schneider C., Teufel A., Yevsa T., Staib F., Hohmeyer A., Walenda G., Zimmermann H.W., Vucur M., Huss S., Gassler N., Wasmuth H.E., Lira S.A., Zender L., Luedde T., Trautwein C., Tacke F. Adaptive immunity suppresses formation and progression of diethylnitrosamine-induced liver cancer. Gut. 2012. 61(12): 1733.

27. Reinhardt A., Yevsa T., Worbs T., Lienenklaus S., Sandrock I., Oberdorfer, L., Korn T., Weiss S., Forster R., Prinz I. Interleukin-23-Dependent $\gamma / \delta$ T Cells Produce Interleukin-17 and Accumulate in the Enthesis, Aortic Valve, and Ciliary Body in Mice. Arthritis Rheumatol. 2016. 68(10): 2476.

28. Wolf B., Krieg K., Falk C., Breuhahn K., Keppeler H., Biedermann T., Schmid E., Warmann S., Fuchs J., Vetter S., Thiele D., Nieser M., Avci-Adali M., Skokowa Y., Schöls L., Hauser S., Ringelhahn M., Yevsa T., Heikenwalder M., Kossatz-Boehlert U. Inducing differentiation of premalignant hepatic cells as a novel therapeutic strategy in hepatocarcinoma. Cancer Res. 2016. 76(18): 5550.

29. Gorobets S.V., Gorobets O.Yu., Gorbyk P.P., Uvarova I.V. Functional bio- and nanomaterials for medical purposes. (Kyiv: Condor, 2018). [In Ukrainian].

30. Uvarova I.V., Gorbyk P.P., Gorobets S.V., Ivashchenko O.A., Ulyanchenko N.V. Medical nanomaterials. (Kyiv: Naukova dumka, 2014). [In Ukrainian].

31. Gutorov S.L., Semenova N.N., Zagrekova E.I. New drugs in the treatment of solid tumors. Russian Medical Journal. 2001. 9(22): 1017. [In Russian].

32. Plentz R.R.; Malek N.P. Systemic Therapy of Cholangiocarcinoma. Visceral Medicine. 32(6): 427.

33. Jain A., Kwong L.N., Javle M. Genomic Profiling of Biliary Tract Cancers and Implications for Clinical Practice. Curr. Treat Options Oncol. 17(11): 58.

34. Firsova N.D. Gemtsitabin. Recent phases II and III of clinical trials in metastatic pancreatic cancer. 2017. https://www.meir-health.ru. [In Russian].

35. Arias J.L., Reddy L.H., Couvreur P. $\mathrm{Fe}_{3} \mathrm{O}_{4} /$ chitosan nanocomposite for magnetic drug targeting to cancer. J. Mater. Chem. 2012. 22(15): 7622.

36. Popescu R.C., Andronescu E., Vasile B.S., Truscă R., Boldeiu A., Mogoantă L., Mogosanu G.D., Temelie M., Radu M., Grumezescu A.M., Savu D. Fabrication and Cytotoxicity of Gemcitabine-Functionalized Magnetite Nanoparticles. Molecules. 2017. 22(7): 1080.

37. Iglesias G.R., Reyes-Ortega F., Checa Fernandez B.L., Delgado Á.V. Hyperthermia-Triggered Gemcitabine Release from Polymer-Coated Magnetite Nanoparticles. Polymers. 2018. 10(3): 269.

38. Patent UA 118524. Gorbyk P.P., Petranovska A.L., Abramov M.V., Turanska S.P., Pilipchuk Ye.V., Opanashchuk N.M., Kulish M.P., Dmitrenko O.P., Busko T.O., Pavlenko O.L., Gorobets S.V., Zakharchuk N.K.. Nanocomposite material. 2019.

39. Moiseenko V.M. Possibilities of monoclonal antibodies in the treatment of malignant tumors. Practical Oncology. 2002. 3(4): 253. [In Russian].

40. Tan M., Yu D. Molecular mechanisms of erbB2-mediated breast cancer chemoresistance. Adv. Exp. Med. Biol. 2007. 608: 119.

41. Santin A.D., Bellone S., Roman J.J., McKenney J.K., Pecorelli S. Trastuzumab treatment in patients with advanced or recurrent endometrial carcinoma overexpressing HER2/neu. Int. J. Gynaecol. Obstet. 2008. 102(2): 128. 
42. Gorodetskaya A. Modern approaches to treatment for disseminated malignant tumors of the gastrointestinal tract. Oncology. 2011. 13(2): 111. [In Russian].

43. Borisenko N.V., Bogatyrev V.M., Dubrovin I.V., Abramov N.V., Gaevaya M.V., Gorbyk P.P. Synthesis and properties of magnetically sensitive nanocomposites based on iron and silicon oxides. V. 1. In: Physical chemistry of nanomaterials and supramolecular structures. (Kyiv: Naukova dumka, 2007). P. 394. [In Russian].

44. Freshny R.Ya. Culture of animal cells: a practical guide (Moscow: BINOM. Laboratory of Knowledge, 2010). [In Russian].

45. Zelentsov V.I., Datsko T.Ya. The use of adsorption models to describe the equilibrium in the system of aluminum oxyhydroxide - fluorine. Elektronnaya obrabotka materialov. 2012. 48(6): 65. [In Russian].

46. Chen D.-X., Sun N., Gu H.-C. Size analysis of carboxydextran coated superparamagnetic iron oxide particles used as contrast agent of magnetic resonance imaging. J. Appl. Phys. 106(6): 063906.

47. Lukyanova N.Yu. Doctoral (Biol.) Thesis. (Kyiv, 2015). [In Ukrainian]. 